\title{
The effects of media on the level of accountability of public organization
}

\author{
Mehrdad Matani $^{\mathbf{a}^{*}}$ and Mahshid Hassanpour ${ }^{\mathrm{b}}$
}

${ }^{a}$ Department of Management, Qaemshahr Branch, Islamic Azad University, Qaemshahr, Iran

${ }^{b}$ Master student of Public management in Islamic Azad University, Qaemshahr Branch, Qaemshahr, Iran

\section{H R O N I C L E}

Article history:

Received March 22014

Accepted 29 July 2014

Available online

August 22014

Keywords:

Media

Public organization

Accountability

Effectiveness

\section{A B S T R A C T}

One of the features of democratic political systems is the accountability against their own performances. Media, one of the powerful elements of civil society and effectual on public thought, plays an important role in making the government responsive. To achieve this goal, the present study tries to investigate the effect of media on the improvement of the accountability level of the government agencies. The statistical society of this research includes all male students of Azad Ghaemshahr University where 320 students were selected through purposive sampling method based on Kerjesy and Morgan table. Applied research method is used in this survey. A researcher-made questionnaire was used to collect the required data. In order to validate the instrument, appropriate questions related to each variable were extracted from valid sources and finally approved by authorities. In order to calculate the reliability of the questionnaire, Cronbach's alpha was calculated to be 89 . Since the distribution of the data was normal, parametric statistical tests were used to testify the hypotheses. The findings of the study show that the media could be effective in terms of making public organizations responsive, through leading and training the public, unifying demands, and monitoring and broadcasting. However, the findings reveal that if the media were free and independent, they would better perform their responsibilities. Finally, the study at hand concludes that in comparison to other media, television is much more powerful in terms of pushing the public sector to be responsive.

\section{Introduction}

A good government has to be responsive. According to Wilson (1887), a good government is both powerful and responsible and as long as power accompanies responsibility, there is no threat. Responsibility in public sector is the basis of the theory, which indicates that officials' decisions and behavior influence strongly on the society. Therefore, the citizens are strongly influenced by the officials' behaviors. How should officials' behaviors be conducted to meet the public benefits? How does a person be ensured that public organizations are functioning regarding the public's benefit? Through encouraging responsibility in public sector, the public's benefits can be guaranteed. Responsibility increases the clarity of the government. Some authorities state that since public trust in the public sector has decreased, there seems to be stronger demand in terms of responsibility (Danai 
fard, 2005). There are different ways to make the public sector's staff responsible. Simultaneous application of these ways to achieve a responsible system is appropriate and desirable. In this condition a set of institutes such as local associations, auditing committees, and media can use their potentials. Mass media are considered as the effective tools for making the government responsible and reflective in terms of people's demands. These tools in a democratic system facilitate idea and information exchange.

Since media form the most crucial communication and information infrastructure, the application of these tools is higher than the predicted level in cultural, economic and political areas. The relation between government and the nation was not as sensitive as it is now. One of the most important reasons of the increase of political sensitivity in societies is the expansion of mass media. From this perspective, the function of media is evaluated in two areas of power and public affairs. In line with this, the functions of media in three different areas: guidance and training people's ideas, monitoring as well as raising awareness about the performance of public organizations are investigated. Public responsibility is a sign of modern democratic management. If those who are in power are not responsible regarding their erroneous behaviors and decisions, democracy will not exist in reality. Therefore, public responsibility has a complementary role in terms of public management in democratic governments (Bovens, 2005).

\section{The proposed study}

Mass media beside political parties comprise civilized societies and function as mediators between people and political system including triple faculties and other political, economic, social and cultural institutions. The role of those mediators is different according to the type of the political system and the extent of freedom in civilized societies. However, generally all of them, especially media play the primary role in meeting the societies' requirements and pushing the government to be responsible. This fact is true to the extent that without them, a government can easily avoid meeting the society's requirements or people can commit aggressive behaviors to express their demands. Nevertheless, the media as a member of a civilized society and a mediator between people's ideas on one hand and government on the other hand train the public in terms of their attitudes and beliefs. Media also unify them toward the performance of the government and directly influence the performance of the governors through expressing social demands and monitoring government performance (Rahbari, 2005). Harold Lassole, an American sociologist, who has accomplished several expansive researches on world war II propaganda determines 3 major roles for media in a society as follows:

1. Monitoring the environment (informative role): monitoring the environment and the necessity of being adjusted to the changes in the society justifies the necessity of broadcasting. In order to continue the social life in a better way, taking their own accountability, people have to be informed about what is going on around them.

2. Developing social unity (guidance role): This reflects the necessity of interpreting the news. Generally, in the form of guiding people's thoughts, not all interpretations are independent from general policies of news. The guidance role of mass media and its role in raising people's awareness are not unknown and it gains importance, constantly.

3. Transferring cultural heritage (training role): Regarding this role specific standards are determined to be transferred to other societies. Mass media propagandize the beliefs related to democracy, freedom, human rights etc., which establish the West in the world.

Generally, based on the theoretical bases of the study, the conceptual framework of the study is presented in Fig. 1 as follows, 


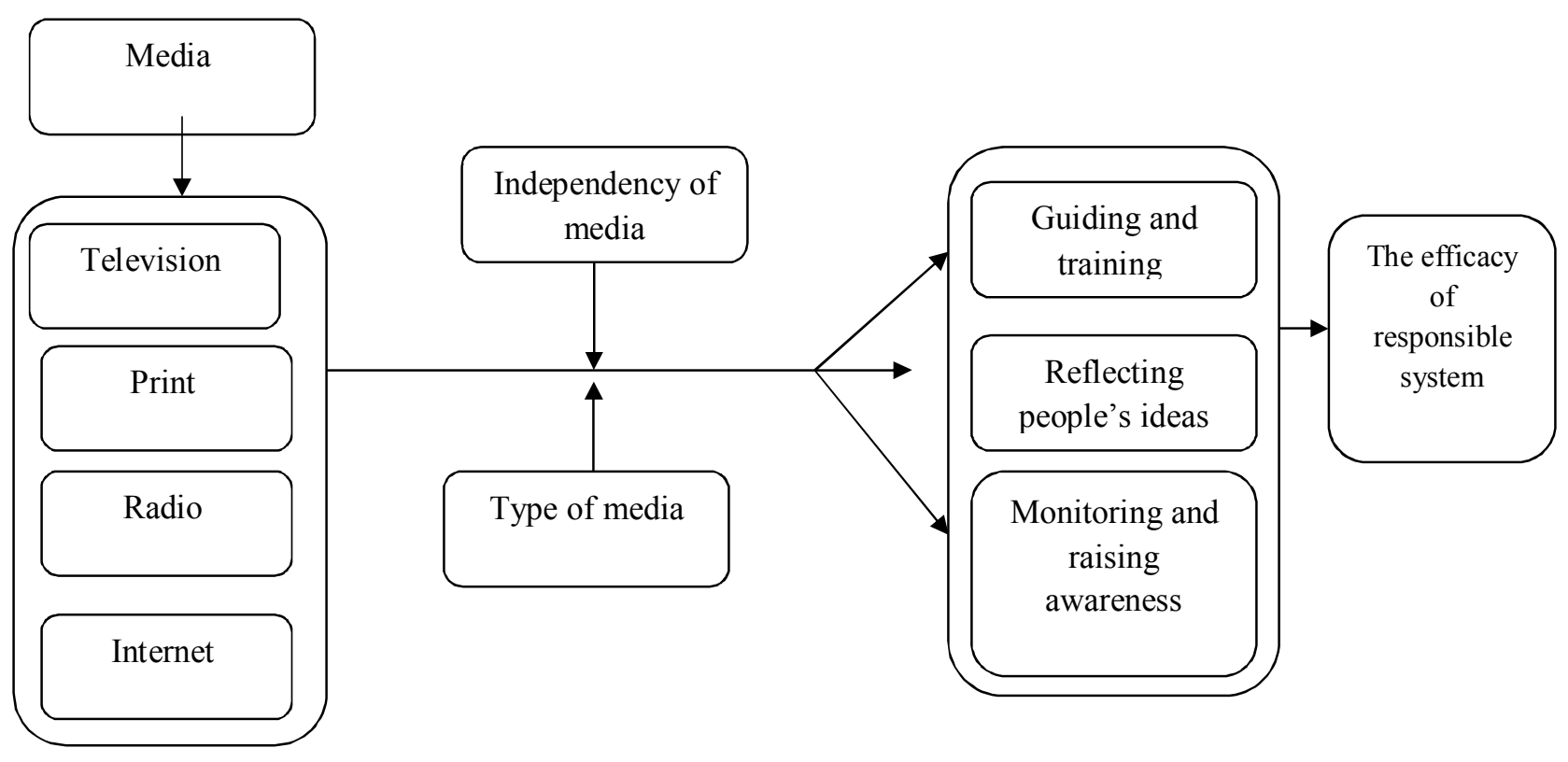

Fig. 1. The proposed study

The proposed study of this paper considers one main hypothesis and four sub-hypotheses.

\section{Main research question}

How do media raise the level of responsibility in public organizations?

\section{Research hypotheses}

1. Media can raise the level of responsibility of public organizations through guiding and training people's ideas.

2. Media can raise the level of responsibility of public organizations through reflecting public demands.

3. Media can raise the level of responsibility of public organizations through monitoring and raising awareness.

4. Existence of free and independent media has stronger effect on raising the level of responsibility in public organizations.

This research is applied in terms of its goal, descriptive in its nature and a survey regarding its type. The population of the study includes all 1492 male students studying at master degree at Islamic Azad University, Qaemshahr branch where 345 students were selected using non-randomized purposeful sampling method and eventually, 320 questionnaires were gathered. The instrument in this research was a researcher-made questionnaire. In order to have a valid instrument, appropriate questions were developed for each variable based on valid sources the validity of which was approved by the authorities.

Cronbach's alpha was calculated to evaluate the reliability of the instrument, which was .89 and it reflects a high degree of reliability of the instrument. To characterize the demographic properties of the sample such as age, sex, position and the type of the organization, related items were included in the questionnaire. In order to measure the main variable of the study, the main aspects of the functions of media were identified in theoretical sources and then the items related to each aspect were developed in five-scale Likert type format the choices of which ranged from totally agree (5) to totally disagree (1). 


\section{The results}

One sample t test was used to analyze the data since the distribution of the data found to be normal.

\subsection{First hypothesis}

The first hypothesis investigates whether media can raise the level of responsibility of public organizations through guiding and training people's ideas. Table 1 demonstrates the results of our survey.

\section{Table 1}

The results of $t$ test- the function of guidance and training of media

\begin{tabular}{lccccccc}
\hline Variable & $\mathrm{N}$ & mean & Standard deviation & $\mathrm{t}$ & $\mathrm{df}$ & $\alpha$ & $\mathrm{p}$ - value \\
\hline Guidance and training & 320 & 3.6 & 0.89 & 12.18 & 319 & 0.05 & 0.0001 \\
\hline
\end{tabular}

As we can observe from the results of Table 1, there is a significance difference between the observed mean (3.60) and the theoretical mean (3). Since the observed t score (12.18) is higher than the critical t-value (1.64) with a degree of freedom equal to 319 at $\alpha=.05$. Hence, the null hypothesis is rejected with $95 \%$ certainty. According to the obtained results, it can be concluded that media can raise the level of responsibility of public organizations through guiding and training.

\subsection{Second hypothesis}

The second hypothesis tries to find out whether or not media can raise the level of responsibility of public organizations through reflecting public demands. Table 2 shows the results of our survey.

Table 2

The results of $t$ test- the function of reflecting people's ideas

\begin{tabular}{lccccccc}
\hline Variable & $\mathrm{N}$ & mean & Standard deviation & $\mathrm{t}$ & $\mathrm{df}$ & $\alpha$ & $\mathrm{p}$ - value \\
\hline Reflecting people's idea & 310 & 3.4 & 0.94 & 8.10 & 319 & 0.05 & 0.0001 \\
\hline
\end{tabular}

According to Table 2, there is a significance difference between the observed mean (3.40) and the theoretical mean (3). Since the observed $t$ score (8.10) is higher than the critical t score (1.64) with a degree of freedom equal to 319 at $\alpha=.05$. Hence, the null hypothesis is rejected with $95 \%$ certainty. According to the obtained results, it can be concluded that media can raise the level of responsibility of public organizations through reflecting public demands.

\subsection{Third hypothesis}

The third hypothesis of this survey studies whether or not media can raise the level of responsibility of public organizations through monitoring and raising awareness. Table 3 demonstrates the results of our survey.

\section{Table 3}

The results of $t$ test- the function of monitoring and raising awareness

\begin{tabular}{lccccccc}
\hline Variable & $\mathrm{N}$ & mean & Standard deviation & $\mathrm{t}$ & $\mathrm{df}$ & $\alpha$ & $\mathrm{p}$ - value \\
\hline Monitoring and raising awareness & 320 & 3.66 & 1.93 & 12.74 & 319 & 0.05 & 0.0001 \\
\hline
\end{tabular}

Similarly, there is a significance difference between the observed mean (3.60) and the theoretical mean (3). Since the observed t score (12.64) is higher than the critical t score (1.64) with a degree of freedom equal to 319 at $\alpha=.05$. Hence, the null hypothesis is rejected with $95 \%$ certainty. According to the obtained results, it can be concluded that media can raise the level of responsibility of public organizations through monitoring and raising awareness. 


\subsection{Fourth hypothesis}

Finally, the last hypothesis of the survey investigates whether or not existence of free and independent media has stronger effect on raising the level of responsibility in public organizations. Table 4 presents the summary of our findings.

\section{Table 4}

The results of $t$ test- the function of media independency

\begin{tabular}{lccccccc}
\hline Variable & $\mathrm{N}$ & mean & Standard deviation & $\mathrm{t}$ & $\mathrm{df}$ & $\alpha$ & $\mathrm{p}$ - value \\
\hline Media independency & 320 & 3.92 & 0.89 & 18.50 & 319 & 0.05 & 0.0001 \\
\hline
\end{tabular}

As it is revealed in Table 4, there is a significance difference between the observed mean (3.92) and the theoretical mean (3). Since the observed t score (18.50) is higher than the critical t-value (1.64) with a degree of freedom equal to 319 at $\alpha=.05$. Hence, the null hypothesis is rejected with $95 \%$ certainty. According to the obtained results, it can be concluded that media can raise the level of responsibility of public organizations through media independency.

\section{Conclusion}

One of the characteristics of a democratic system is its ability to be responsible in terms of government's performance. However, with this regard it is not expected that a government be responsible on its own. This procedure requires its own mechanisms in a civilized society. Media as one of the powerful members of a civilized society plays essential role on increasing the government performance and increases the responsibility. The primary objective of this study was to investigate the role of media in raising the level of responsibility in public organizations. In line with this, the functions of media in three different areas of guidance and training reflecting public demands and monitoring public organizations performance were investigated.

The findings related to the analysis of the first hypothesis showed that media as a member of a civilized society and the mediator between people's ideas and government, played different roles one of which is guiding and controlling society's thoughts and beliefs so that media can guide the public toward an appropriate logical goal through propaganda. Analysis of the findings related to the second hypothesis showed that media could play important role in providing society's requirements and forcing organizations to be responsible so that without media organizations may avoid providing society's requirements. Regarding the third hypothesis, it can be stated that if organizations are aware of being monitored by media, they would always feel being criticized by people. Otherwise, organizations tend to avoid clarity.

Comparing the findings of this research with the ones of the previous studies, there seems to be crucial notes. Rahimi (2003) investigated the responsibility of public organizations to offer a model for empowering the recipients of public organizations services. He found education and media as main tools for empowering citizens and raising public organizations responsibility. Hong (2002) investigated the role of mass media in making a civilized society in Vietnam. In another study, this researcher focused on the role of mass media and modern communication technology in developing clear responsible government. Danai-fard (2002) investigated the responsibility of public organizations in the light of communication technology. He concluded that the role of communication technology is complex and nonlinear. Rahbari (2007) in his theoretical study focused on media and governmental organizations responsibility and concluded that media as one of the powerful members of civilized societies affect people's attitudes and play both political and nonpolitical roles one of which is pushing government to be responsible.

Another part of the findings of the study implies that a moderating variable, media independency is one of the parameters of democratic systems. The findings showed that if media are independent, they may strongly push public organizations to be responsible in terms of their performance. 
To sum up, the overall findings of the study revealed that media could improve the responsibility of organizations through guidance, reflecting public demands and monitoring and raising awareness. If it is accomplished properly, it paves the way for approaching officials and people together, improves the efficacy of the government, increases people's participation in decision making.

\section{References}

Aucoin, P., \& Heintzman, R. (2000). The dialectics of accountability for performance in public management reform. Governance in the Twenty-first Century: Revitalizing the Public Service, 244-280.

Bovens, M. (2005). Public accountability. The Oxford handbook of public management, 182-208.

Chapman, R. A. (Ed.). (1993). Ethics in public service (Vol. 10). Edinburgh University Press.

Danai-fard, H. (2005). Responsibility in public organization: Does information technology increase responsibility? Management and Development Quarterly, 16.

Dubnick, M. J. (2002, August). Seeking salvation for accountability. In Annual Meeting of the American Political Science Association (pp. 7-9).

Faghihi, A. (2001). Responsible systems in public sector. Management Studies, 24.

Gholipour, R. (2008). Governing well and an appropriate model of government. Tehran: Islamic Azad University.

Hong, H.T. (2002). Media and civil society in support of good governance in Vietnam. Media Asia Journal, 29, 24.

Hughes, O. E. (2012). Public management and administration. Palgrave Macmillan.

Mehdizadeh, M. (2005). A comparative study of the theory of in communication. IRIB Research Center.

O'Connell, L. (2005). Program accountability as an emergent property: The role of stakeholders in a program's field. Public Administration Review, 65(1), 85-93.

Romzek, B. S. (2000). Dynamics of public sector accountability in an era of reform. International Review of Administrative Sciences, 66(1), 21-44.

Rahbari, M. (2005). Media and the responsibility of public organizations. Research and Measurement, 12 (41).

Rahimi, G. (2003). Responsibility of organizations: empowering the recipients of public services and offering an appropriate model. Unpublished doctoral dissertation. Allame-Tababaii University.

Wilson, W. (1887). The study of administration. Political science quarterly, 2(2), 197-222. 